\title{
Mental Self-Exploration in Samuel Beckett's Molloy: A Jungian Approach
}

\author{
Ali Jamalinesari \\ Department of English Language and Literature, Islamic Azad University, Ilam Branch, Ilam, Iran \\ E-mail: jamalinesari@yahoo.com \\ Nabieh Feilinezhad \\ Young Researchers and Elite Club, Ilam Branch, Islamic Azad University, Ilam, Iran \\ E-mail: nfilinezhad@yahoo.com
}

Doi:10.7575/aiac.alls.v.6n.1p.11

URL: http://dx.doi.org/10.7575/aiac.alls.v.6n.1p.11
Received: 28/08/2014

Accepted: 06/11/2014

\begin{abstract}
Samuel Beckett is categorized as an absurdist dramatist. Martin Esslin in his book The Theatre of Absurd, states that absurdist writers dealt with the theme of man's sense of anguish and torture caused by living without any purpose. All characters of Beckett's dramas are deformed just like Molloy who deteriorates as the novel comes to an end. Actually, Beckett's characters are wanderers who try to establish a sense of meaning for their existence; they are in search of self. As his works represent, Beckett uses Jungian archetypes in order to show the aspect of self. This article tries to demonstrate the lack of identity in Molloy's Characters in the light of Jungian archetypes throughout the story.
\end{abstract}

Keywords: Molloy, Identity, Archetype, Jung, Self, Deterioration

\section{Molloy}

Molloy (1977) is a novel which has two parts; the first part includes Molloy's search for his mother, and the second part is about Moran's search for Molloy. In the first part, Molloy is trapped in his mother's room, writing a report which every week a stranger comes and gets these papers and in return gives him money. One day, as he was looking out of the window, he saw two persons " $\mathrm{A}$ and $\mathrm{C}$ on a road who were going toward each other, unconscious of what they were doing." (1977, p.5) Later after seeing them, Molloy decided to go after his mother whom he did not know where she was. At the beginning of his journey, Molloy suffered from one of his stiffening legs. He used his bicycle and set off his journey. On his journey, first he went to a city where he did not know where it was. In the city, the police arrested him and took him to the police station. There he was investigated to say his name and show his identification card, but soon he was freed on the occasion that they discovered him a miserable man. After that, on the way to his journey he hit a dog on the street with his bicycle. The owner of the dog, Lousee, asked him to help her with the dog to bury him and wanted Molloy to stay with her all long. Molloy accepted and stayed with her for some months; there Lousee treated him like a mother, but after sometimes Molloy decided to follow his journey. He left his bicycle and the things he had there and continued his way without knowing where to go exactly. He passed the streets and reached the jungle where now his both legs stiffened. As he went more and more, he became weaker and weaker. In the jungle he saw a charcoalburner, who invited him to his hut; but Molloy killed him. Gradually, Molloy became weaker and was not able to walk. Therefore, he crawls on the ground and finally he was trapped into a ditch. There he waited for a help regardless of his disappointment.

The second part of the novel is about Moran, a detective who is obliged to find Molloy. Moran is a detective who works for an organization which is managed by Youdi. One evening Gaber, a messenger from Youdi, came to Moran and said to him that he had to find Molloy. Moran took his son with him for the journey. From the beginning, just like Molloy, one of Moran's leg stiffened. On their way, they passed a forest just like Molloy. Moran gave his son some money in order to buy a second-hand bicycle, and stayed in jungle for rest. On the first day, when his son left him, he saw a stranger who came near to him with stick. To him he was too old, and dressed in such a way that he had not seen before. The stranger asked bread and Moran gave him one, and after that the stranger went away. On the second day, again Moran saw a man who was in search of a man with stick, whom had been passed by earlier. At this time, Moran killed the man, and waited for his son to return. On the third day, his son returned with a second-hand bicycle. After some days they reached to Ballyba, Molloy's city. They took refuge in a camp and rested. Due to his bad behavior toward his son during the journey, the day after reaching the city his son left him. Moran was so weak and his other leg began to stiffen, too. At this time, Gaber arrived and said to him that his mission was finished and he had to return home. When he returned home, he saw that everything had been changed. His family had left him, and his house had been collapsed. At the end like Molloy, he had to report everything to his organization. 


\section{Jungian Approach on Molloy}

As Jung (1969) claims, anima is a female aspect within a man. In fact, it is the opposite sex which appears in literary works. In Molloy, anima appears with Molloy's mother, Lousse, and Ruth. Since Jung states that the mother archetype can be regarded as a kind of anima, first there is the exploration of mother archetype in the sense of anima.

Molloy cannot remember his mother's name. It shows his bad memory of the past or his ignorance and reluctance toward his mother. He called her 'Mag', which resembles to the word 'Ma'. Molloy says that:

I called her Mag, when I had to call her something. And I called her Mag because for me, without my knowing why, the letter $\mathrm{g}$ abolished the syllable Ma, and as it were spat on it, better than any other letter would have done. And at the same time I satisfied a deep and doubtless unacknowledged need, the need to have a Ma, that is a mother, and to proclaim it, audibly. For, before you say mag, you say ma, inevitably. (1977, p.15)

Molloy does not have a good view point about his mother. Actually, he hates her and this hatred is shown in their communication that they did not have, except the moment when Molloy knocks her skull in order to make a communication. (1977, p.15) He even states about his mother's appearance "the shrunken, hairy old face" (1977, p.15), which is not satisfying to him. He claims that his mother was not able to talk, or understand anything. He calls her "the poor old uniparous whore, deaf, blind, impotent woman." (1977, p.17) In fact, Molloy's mother represents the negative aspect of anima or mother archetype. He convicts his mother of having born him into this world "that old bitch, gives a kind of her lousy unconquerable genes." (1977, p.89) At first, Molloy did not intend to go and find his mother, since there passed a long time during his life and he did not search for his mother; it seems that his mother was not important for him. But when he saw A and C, and heard the angelic voice, he decided to go after his mother. At the end, he did not find his mother and just he was in his mother's room, lying down. Therefore, his search for his mother was not successful. And since searching for mother means searching for the meaning and self, consequently, he did not find meaning in his life and did not reach his self.

Another woman in the story is Lousse, whom Molloy hit her dog with his bicycle and killed it. Lousse might be regarded as a Jungian mother archetype and anima. When Molloy killed her dog, she forgave him on the condition that to help her to bury the dog. She helped him, provided food, and treated him like a mother "they had carried their impertinence to the point of washing me, to judge by the smell I gave off... They have shaved me." (1977, p.39) In fact, these actions have been done based on Lousse's orders. In this regard, Molloy is treated as a son and Lousse is like a mother, and he is satisfied in living there:

I could not prevent her having a weakness for me, neither could she. I would live in her home, as though it were my own. I would have plenty to eat and drink, to smoke too if I smoked, for nothing, and my remaining days would glide away without a care. I would as it were take the place of the dog I had killed, as it for her had taken the place of a child. I would help in the garden, in the house, when I wished, if I wished. I would not go out on the street; for once out I would never find my way in again. I would adopt the rhythm of life which best suited me, getting up, going to bed, and taking my meal at whatsoever hours I pleased...All she asked me was to feel me near her, and the right to contemplate from time to time this extraordinary body both at rest and in motion. (1977, p. 50)

On the other hand, Lousse is described as a negative character, in spite of being described more positive than Molloy's mother. Molloy believed that she was going to poison him gradually "and doubtless she had poisoned my beer" (1977, p.49), in order not to let him go away from her. Because, for several times he asked Lousse that where was he now and which way he had to go, but she did not reply him; because she wanted him to stay there. Therefore, he is suspicious about her with poisoning his beer. In fact, Lousse or Sophie Loy (another name for Lousse which Molloy uses because he does not know her exact name) represents Jung's archetype of wisdom. In Jung's theory the name Sophia is the feminin archetype of wisdom. Here, Molloy spoke about her as a seductive person who tried to poison him. Ironically, here Molloy draws a negative picture of Lousse, who is trying to prevent Molloy from his journey. Consequently, Lousse functions as a negative anima. Finally, one day Molloy escaped from her house secretly and continued his journey. In this regard, once again Molloy was not able to accept his anima and failed to reach his self.

The third woman who represents Molloy's anima is Ruth, whom Molloy had a sexual relationship with her. Molloy saw Ruth in "a rubbish dump." (1977, p.61) Like Lousse, Ruth's identity is not clear, since Molloy called her as Ruth and sometimes as Edith "she went by the peaceful name of Ruth I think, but I cannot say for certain. Perhaps the name was Edith." (1977, p.60) But, he was suspicious that if that was a true love or not "perhaps after all she put me in her rectum... but is it true love in the rectum?" (1977, p.61) Moreover, Molloy doubted that even if she was a man as he states that "Perhaps she too was a man." (1977, p.61)

Molloy actually is searching for a fellow; that is why at first he decided to go after his mother. Then he saw Lousse and Ruth. But, in fact, he was not able to find his mother, and was not able to communicate with Lousse and Ruth. Actually, whenever Molloy wanted to know a woman and make a relation with her, immediately he disgraces her and moves away. Therefore, he was not able to achieve his self. 
As Jung (1969) declares, one of the aspects of achieving the process of individuation is mandala, any circle image with squares. In this story, Molloy faced this aspect but unconsciously left it. After leaving Lousse and Ruth, Molloy continued his search for his mother. When he left the town, he reached the forest, where he came to the center of it, to the crossroad. He says:

The forest was all about me and the boughs... From time to time I came on a kind of crossroad, you know, a star, or a circus, of the kind to be found in the even most unexplored of the forest. And turning then methodically to face the radiating paths in turn, hoping for I know not what, I described a complete circle, or less than a circle, or more than the circle, so great was the resemblance between them. $(1977$, p.91)

The mandala image shows the psychic wholeness of the person that one can reach it through recognizing it. In the forest, in this crossroad, Molloy saw a charcoal-burner, who invited him to his hut to rest and stay with him for the rest of his life. Molloy asked him the way to the nearest town but he did not answer him and just wanted Molloy to stay. Actually Molloy does not know the charcoal-burner's name or if his job is really that. He just guessed that by the evidences "I say charcoal-burner, but I really do not know. I see smoke somewhere." (1977, p.92) Therefore, the charcoal-burner represents Molloy's ego-consciousness. Since Molloy wanted to find his mother, he refused to stay with him. But the charcoal-burner tried to prevent him and Molloy killed him by his crutches and left the place. In Jungian terms when a person recognizes this image, he will find his wholeness. But, here, Molloy unconsciously left it in order to find his mother which is the symbol of meaning for him, despite his failure for that, too. Actually, he thought that if he leaves the place, he will find the meaning through his mother, but he was wrong. Consequently, Molloy moved from his wholeness toward the worse aspect of his nature which is his beastly aspect, because he killed the charcoal-burner just like an animal.

As mentioned, when Molloy saw A and $\mathrm{C}$ he made up his mind to go and find his mother. When he saw them, he described one of them (C) as" bare-headed, wore sand-shoes, smoked a cigar... followed by a dog" (1977, p.8) and " he looks old and it is a sorry sight to see him solitary after so many years, so many days and nights unthinkingly given to that rumor rising at birth and even earlier." $(1977$, p.6) This rumor at birth can be an allusion to Christ's birth, which this man considered to be a Christ figure who symbolizes the wise old man. Therefore, Molloy decided to follow him "I watched him recede, at grips (myself) with the temptation to get up and follow him, perhaps even to catch up with him one day, so as to know him better, be myself less lonely." (1977, p.7) These words show Molloy's desire for getting knowledge and having a fellow man. In spite of having desire for knowledge, Molloy was not able to reach the man and states:

But in spite of my soul's leap out to him, at the end of its elastic, I saw him only darkly, because of the dark and then because of the terrain, in the fold of which he disappeared from time to time, to re-emerge further on, but most of all I think because of other things calling me and toward which too one after the other my soul was straining. (1977, p.8)

In this aspect, Molloy failed to reach the wise old man because he did not talk to him or even reach him. Another aspect of the wise old man is the shepherd whom Molloy saw when he decided to find his mother. Actually, shepherd is the traditional sign for wise old man, Jesus or prophets. One morning when Molloy opened his eyes he saw a shepherd with his dog watching him laid down. At this time Molloy asked the shepherd a question that if he is taking the flock to the fields or slaughter house; because the field for Molloy represents the salvation, the right way, and fertility. By these words, he wanted to know whether his soul can achieve this salvation and the right way. But the shepherd did not answer him and moved on to his way. In this story, all the wise old men were not able to answer Molloy, fulfill his curiosity, and save him; they fail to cover their role. In Molloy's story, one can trace the archetypes. Based on the Jungian theory, the process of individuation is the bridge for a person to achieve his self and identity. Since Molloy was not able to integrate all these archetypes into his consciousness, and his search was not a successful one, therefore, he failed to reach his self.

Moran is a detective who is obliged to find Molloy. He has a son and a maid. It seems that he is a wealthy, religious man from a good family who has a high rank in society. Like Molloy, he is in search of the self and meaning. Actually, Moran has a social mask. Based on Jung's archetype (1969), persona (mask) is a kind of mask that each individual wears in order to hide his true nature and identity from the others. In this novel, Moran is described as a religious man who goes to church every Sunday and pretends to have a strong belief in God. When Gaber came to him and gave the instructions the time passed and Moran says, "It was too late for mass. I did not need to consult my watch to know, I could feel mass had begun without me. I who never missed the mass, to have missed it on that Sunday of all Sundays! When I so needed it." (1977, p.105) This shows that he was sad by missing that Sunday worshipping. On the other hand, he even forces his son to go to the church on Sundays too, and he doubted that if his son has really gone to the church that day and asked Father Ambrose "if he had noticed his son at the last mass." (1977, p.111) All of these show that he is so strict in his beliefs. But later, little by little he looses his faith. For example, when he was disappointed and confused with his journey he asked "the Lord for guidance." (1977, p.112) Later, he says that "God is beginning to disgust him," (1977, p.117) or in the last part of his journey when he was lying in forest he asked himself some theological and religious questions that "would I go to heaven? Is it true that the devils do not feel the pains of hell? 
What was God doing with himself before the creation?"(1977, p.189) These ideas make him disappointed and gradually shatter his beliefs.

The other mask that he has is his relationship with his son. Actually, he loves his son as he states, "did he love me then as much as I loved him?" (1977, p.134) But, he is so strict and serious toward him and wears a violent paternal mask about his son. When he reprimands his son he feels pity on him, too. He says:

I was sometimes inclined to go too far when I reprimanded my son, who was consequently a little afraid of me. I myself had never been sufficiently chastened. Oh, I had not been spoiled either, merely neglected. Whence bad habits ingrained beyond remedy and of which even the most meticulous piety has never been able to break me. I hoped to spare my son this misfortune, by giving him a good clout from time to time, together with my reasons for doing so. (1977, p.106)

This shows that he just wants to act severely in order to treat his son in a best way. In fact, this is his mask that he has for his son, just as Jung says that one has a mask even in his familial relationship. Moran sets a kind of father image to his son, a kind of father who acts like a paternal shadow. Jung (1956) explains that "the father acts as a protection against the dangers of the external world and thus serves his son as a model persona" (p.208), consequently, whatever Moran denied in himself, and whatever he wished to be, tried to make in his son. For example, he says, "I controlled myself. He was wiping his mouth with the back of his hand, a thing I do not like to see. But there are nastier gestures, I speak from experience."'(1977, p.110) Therefore, Moran's violence toward his son increases and he tries to suppress his son's actions. For instance, he states:

Out? I said. Where? Out! Vagueness I abhor [...] to the Elms he replied. So we call our little public park. And yet there is not an elm in it, I have been told. What for? I said. To go over my botany, he replied. There were times I suspected my son of deceit. This was one. I would almost have preferred him to say, for a walk, or, to look at the tarts. The trouble was he knew far more than I, about botany. Otherwise I could have set him a few teasers, on his return. $(1977$, p.111)

In other parts, during his journey with his son, one can see more instances of these cruelties. For example, he wants his son to pedal the bicycle regardless of his sickness. Consequently, with these cruelties and bad behaviors, one morning his son left him. (1977, p.181) In this regard, one can trace the concept of mask in Moran, who in his social interactions and familial relationships with his son hides his real nature. He did not have a strict belief in God or religion, but just pretends to be the one like. Moreover, his reaction toward his son shows that he loves his son but wants him to act in a good way; but it had a reversal effect.

The only woman in this story is Martha who works in Moran's house. It seems that there is not a good relationship between them. Moran is cold and strict to Martha and at the same time he is afraid of her too with regard that she may hurt him. For instance, when Moran says to her "you will not go out today" immediately "knowing her capable of poisoning him", he gives an opportunity to her to go out the next day to avoid her from poisoning him. (1977, p.108) In addition, Moran does not like to let Martha interfere to his personal life and he tries to put her away from his affairs. For example, he did not tell her that they were leaving the house because he could not trust her:

I had not yet told her we were leaving. I would not tell her the last moment, one foot in the stirrup as the saying is. I did not wholly trust her. I would call her at the last moment and say, Martha, we are leaving, for one day, two days, three days, a week, two weeks, God knows, goodbye. It was important to leave her in the dark. (1977, p.116)

But his effort is vain since she knows about their leaving, as she says, "you ought to eat something hot, before you leave. And who told you I was leaving? [...] I am not blind, she said."(1977, p.131)

Consequently, this kind of relationship shows that Martha and Moran are not able to communicate and trust each other and try to hide everything; in fact, they try to overcome the other side. Although Martha is the servant in the house, she tries to insist and impose her ideas on Moran:

The rocking-chair, she would have you believe, was the only possession to which she clung and she would not have parted with it for an empire [...]. It is interesting to note that she had installed it not in her room, but in the kitchen [...]. In the kitchen all must be of wood, white and rigid. I should mention that Martha had insisted, before entering my service that I permit her to keep her rocking-chair in the kitchen. I had refused, indignantly. Then, seeing she was inflexible, I had yielded. (1977, p.121)

This matter shows that Moran and Martha just try to come along with each other. There is not any love between them. But, when Moran wants to leave, he goes to see Martha for the last time: 
I went to the kitchen [...]. Martha watched me in silence, lolling in her rocking chair [...]. Then almost in the same breath, seeing her so old, worse than old, ageing, so sad and solitary in her ever-lasting corner, There. I advised her [...] to have a good rest while I was away and a good time visiting her friends [...]. I carried this sudden cordiality so far as to shake her hand by the hand [...]. When I had finished shaking it, that flabby red hand, I did not let it go. But I took one finger between the tips of mine, drew it towards me and gazed at it. And had I had any tears to shed I should have shed them then. (1977, p.135)

This part of reaction shows that Moran for a short time feels pity on her, which during all his life he was not aware of her. Therefore, although Moran feels pity on her again he is not able to say anything and show his sympathy. On the other hand, Martha did not say any words to sympathize with Moran and just was wondered if "Moran was not on the point of making an attempt on her virtue." (1977, p.135) So, Moran's integration with anima again fails.

Moran faces with wise old man too, like Molloy. When he and his son go to Ballyba, they see a shepherd with his dog and the flock. By seeing the shepherd, Moran decides to go to them "leaving my son I went toward them [...] now I was in the midst of the sheep." (1977, p.179) Moran did not say anything to the shepherd and no words were exchanged between them; in his longings he wanted to say "take me with you; I will serve you faithfully, just for a place to lie and a little food."(1977, p.180) Finally, the shepherd and his flock leave him alone. Here, one can see the failure of the integration of Moran with wise old man, since if the shepherd represents the wise old man, he must help him with his journey. But here they did not talk to each other and Moran's desire as a faithful follower remained without any result.

\section{Conclusion}

According to Jung (1969) every man can achieve his self through the process of individuation. In order to achieve the process of individuation, one must integrate the archetypes into his conscious mode. In Samuel Beckett's Molloy, the characters of Molloy and Moran were not able to integrate their animas to their consciousness. Moreover, the wise old man was not able to help them. Apart from all, Moran wore a mask too. The characters did not reach their selves; so, since the process of individuation did not take place and the archetypes did not integrate to the conscious where it is a place for identity, the characters did not achieve their meanings and deteriorate through the ending of the story. As one can see, Molloy at the beginning of his journey was able to walk, while at the end of story he could not walk and crawled on the ground.

\section{References}

Beckett, S. (1977). Molloy, Malone Dies and The Unnamable. New York: Alfred A.Knopf.

Esslin, M. (1980). The Theatre of the Absurd. London: Cox \& Wyman Ltd.

Jung, C.G. (1969). The Archetypes and the Collective Unconscious. New York: Princeton University Press. 